\title{
Parental effects in the European sardine Sardina pilchardus
}

\author{
I. Riveiro*, C. Guisande, I. Maneiro, A. R. Vergara \\ Universidad de Vigo, Campus Lagoas Marcosende, Vigo 36200, Spain
}

\begin{abstract}
Positive parental effects, defined as the strategies displayed by sardine Sardina pilchardus adults to increase the survival of eggs and larvae, were studied off the coast of the Iberian Peninsula (Spain) by monthly sampling of eggs and larvae in Ría de Vigo, over a period of 4 yr. Two different parental strategies were observed over the spawning period: temporal variations in spawning intensity, and variation of egg quality. Sardine spawn outside the upwelling season, to avoid offshore transport of eggs and larvae to where food is less abundant. There is a negative correlation between the duration of embryonic development and egg organic content. Sardine employ a parental strategy that adapts the biochemical composition of eggs to the evolution of the temperature in the area during the spawning season. Eggs of higher organic content are produced in the coldest months, thereby compensating for the delay in embryonic development time due to low temperatures. This also has the effect of enhancing larval survival.
\end{abstract}

KEY WORDS: Parental strategies $\cdot$ Reproduction $\cdot$ Fish $\cdot$ Egg $\cdot$ Larva

\section{INTRODUCTION}

Reproduction incurs a very high cost in energy (Hutchings 1994, Millán 1999, Skolbekken \& UtnePalm 2001) and increases the probability of death after spawning for adults (Hutchings 1994). This important investment has to be undertaken with the aim of maximizing success for the offspring and, as a consequence, parental effects arise. These can be defined as the different tactics employed by fish populations to increase survival of their eggs and larvae. Among these effects are variations in the spawning season and egg quality, and a wide variety of parental care tactics (Sargent et al. 1987, Chambers \& Waiwood 1996, Imai \& Tanaka 1998, Marteinsdottir \& Steinarsson 1998).

Given that pelagic species of fish, in particular the Clupeidae, are abundant in areas of upwelling (Fréon et al. 1997, Cole \& McGlade 1998, Cury et al. 2000), their reproductive strategies have to be adapted to these regimes. The upwelling is biologically very important because it produces an enrichment of the waters essential for primary production. However, for reproduction to be successful, processes of concentra- tion (stability of the water column, convergence and formation of fronts) and retention of the eggs and larvae in the appropriate area are necessary (Bakun 1986).

Another parental strategy is the variation of egg quality, which can be defined as all egg characteristics, and subsequently those of the larvae, affecting larval survival. One of the most studied characteristics is egg size, which influences the survival of the fish during the initial phases of life by influencing larval activity and growth rates (Blaxter \& Hempel 1963, Banegal 1969, Hunter 1981, Miller et al. 1988, Hinkley 1990, Araújo-Lima 1994). Usually, a reduction in egg size is observed as the spawning season progresses and the quantity of food available increases (Hinckley 1990, McEvoy \& McEvoy 1991, Baynes \& Howell 1996). However, many authors maintain that egg size (or diameter) is not a good indicator of the quality of the spawn (Devauchelle \& Coves 1988, Lagomarsino et al. 1988, Nissling et al. 1998), and that larval characteristics are determined by other variables such as size, condition and age of the adult females (Kristjánsson \& Vøllestad 1996) or the biochemical composition of the egg (Craik \& Harvey 1987, Devauchelle \& Coves 1988, 
Srivastava \& Brown 1991, MacKenzie et al. 1996, Pickova et al. 1997).

A large variety of biochemical parameters are used to characterize the physiological condition of the first life stages of fish and aquatic invertebrates. For the study of eggs and larvae these include amongst others: the ratio RNA/DNA (Buckley et al. 1991, Bisbal \& Bengtson 1995, Rooker \& Holt 1996, Suthers et al. 1996, Chícharo et al. 1998), protein and amino acid content (Fyhn \& Govoni 1995, Rønnestad et al. 1998, 1999, Sivaloganathan et al. 1998), enzymatic activity (Farris 1960, Takii et al. 1997), content of lipids and fatty acids (Finn et al.1995, Gunasekera et al. 1999) and content of carbohydrates (Srivastava \& Brown 1991).

Current knowledge of the biochemical composition throughout embryonic and larval development is based upon studies undertaken in rearing systems and also in analysing how differences in composition affect hatching success and larval mortality (Planas et al. 1991, Tamaru et al. 1992, Finn et al. 1995, Gunasekera et al. 1999). Although numerous studies have been carried out with artificially fertilised eggs in culture tanks, little is known of what happens in a natural environment.

In natural populations, starvation is thought to be one of the main causes of larval mortality when the larvae move towards exogenous feeding (Canino et al. 1991, Bailey et al. 1995). Hence, the quantity and composition of vitellus that the egg and/or larva possesses can be of considerable importance as an eventual determinant of larval condition in the first days of life and, therefore, may influence mortality in situations of food limitation (Srivastava \& Brown 1991, Brown \& Taylor 1992, Riveiro et al. 2000).

The biochemical constituents of the egg are important, but the effect of external variables, mainly temperature, cannot be ignored. Given that the quantity of yolk in the egg affects the survival time without food of the resulting larva, the effect of temperature upon the yolk absorption rate ought to be considered when relating egg quality and larval survival (Hart \& Purser 1995, Kucharczyk et al. 1997). Egg development is achieved depending upon the energy available and the efficiency of the conversion rate from yolk to body structures. At high temperatures there are faster development rates and a higher speed of conversion (Hart \& Purser 1995, Kuyawa et al. 1997, Pepin et al. 1997). However, usually the conversion of the yolk has a somewhat lower efficiency, and this is translated into smaller larval size at hatching as the temperature of incubation increases (Kamler et al. 1994, Pepin et al. 1997). In some species such as cod Gadus morhua, temperature is the main factor affecting embryonic development, and egg size does not have important implications for the future characteristics of the fish (Pepin et al. 1997).

The aim of the present study was to investigate the reproductive strategies of sardine Sardina pilchardus, employed to enhance egg and larval survival during the spawning season in the northwest Iberian Peninsula.

\section{MATERIALS AND METHODS}

Field study. From February 1998 to December 2001, fertilised Sardina pilchardus eggs and larvae were collected monthly from the Ría de Vigo (northwest Spain) using the RV 'Jose $\mathrm{M}^{\mathrm{a}}$ Navaz' at 4 stations: $11\left(42^{\circ} 7.8^{\prime} \mathrm{N}\right.$, $9^{\circ} 7.5^{\prime} \mathrm{W} ; 148 \mathrm{~m}$ depth), $13\left(42^{\circ} 8.5^{\prime} \mathrm{N}, 8^{\circ} 57.5^{\prime} \mathrm{W} ; 97 \mathrm{~m}\right.$ depth), $14\left(42^{\circ} 12.8^{\prime} \mathrm{N}, 8^{\circ} 51^{\prime} \mathrm{W} ; 39 \mathrm{~m}\right.$ depth) and 15 $\left(42^{\circ} 13.3^{\prime} \mathrm{N}, 8^{\circ} 47.7^{\prime} \mathrm{W}\right.$; $29 \mathrm{~m}$ depth) (Fig. 1).

Ichthyoplankton samples were collected using a $50 \mathrm{~cm}$ diameter Bongo sampler fitted with $335 \mu \mathrm{m}$ mesh aperture nets, towed obliquely from about $5 \mathrm{~m}$ above the bottom to the surface at a speed of approximately 2 knots. Each sample was transported in 301 of seawater to the laboratory, where samples were analysed within $4 \mathrm{~h}$ of collection.

To establish quantity and quality of the seston, as an indicator of food available for the larvae, vertical net hauls using a $20 \mu \mathrm{m}$ mesh net (equipped with flowmeter) were towed at each station from the same depth as the ichthyoplankton samples. The fraction 20 to $1000 \mu \mathrm{m}$ was resuspended in 11 of filtered seawater and subsamples were then filtered through GF/F Whatman filters and frozen at $-32^{\circ} \mathrm{C}$ for subsequent biochemical analyses. CTD (Seabird 25) profiles were carried out at all stations.

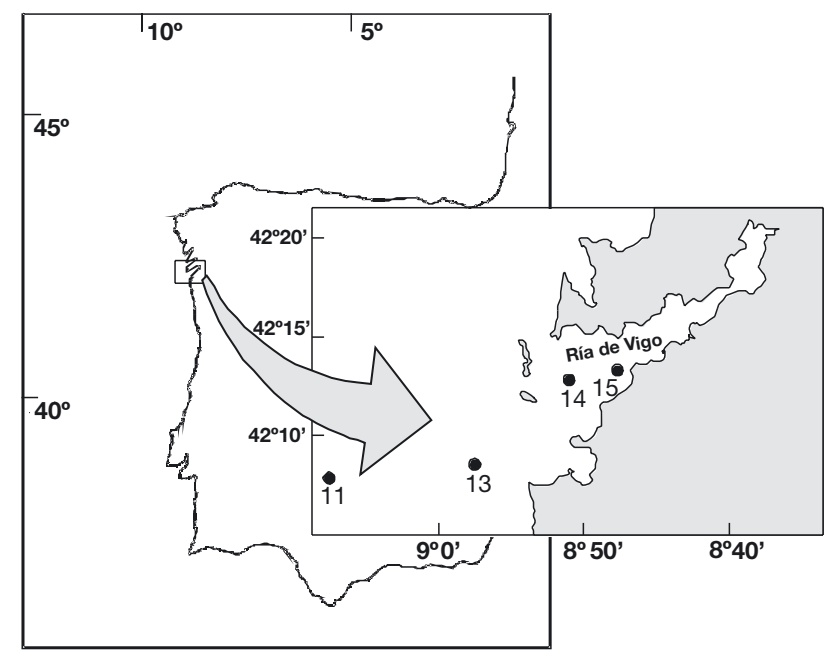

Fig. 1. Study area (northwest Iberian Peninsula, Spain) showing sampling stations 
Ekman transport. Ekman transport data for 1875 to 1997 from a station located at $42^{\circ} \mathrm{N}, 10^{\circ} \mathrm{W}$ was extracted from the COADS standard data set (available at: www.cdc.noaa.gov/coads/products.html) (Woodruff et al. 1987). The Atlantic northwest coast of the Iberian Peninsula has a north-south orientation and hence, northern winds produce offshore transport. Therefore, Ekman transport along the $x$-axis $\left(Q_{\mathrm{x}}\right)$ is a good indicator of larval drift offshore during the sardine spawning season. Negative values of $Q_{\mathrm{x}}$ would indicate water transport offshore, whereas positive $Q_{\mathrm{x}}$ values would indicate water transport onshore.

Embryonic development study. Sardine eggs were isolated in the laboratory. The developmental stage was determined following the criteria of Gamulin \& Hure (1955), and measured using a binocular microscope fitted with an ocular micrometer. Subsequently, Stage II eggs were placed individually in assay tubes with $10 \mathrm{ml}$ of filtered seawater (from the stations where the eggs were collected) through $0.45 \mu \mathrm{m}$ of GF/F (glass microfibre filters) and stored at different temperatures $\left(12,14\right.$ and $\left.16^{\circ} \mathrm{C}\right)$ under a $12: 12 \mathrm{~h}$ light:dark cycle. Eggs were inspected every $6 \mathrm{~h}$ to record hatching time.

Biochemical analysis. Eggs and larvae were collected to analyse protein, carbohydrate and lipid content. After staging and measuring, 1 larva or 2 eggs of similar size and stage of development were transferred to an ultracentrifuge plastic tube with $600 \mu \mathrm{l}$ of bi- distilled water. Samples were homogenised using a pipette tip adapted to fit the shape of the vial. A volume of $200 \mu \mathrm{l}$ of each egg homogenate was used for protein analysis, $200 \mu \mathrm{l}$ for carbohydrate analysis and $75 \mu \mathrm{l}$ for lipid analysis. Table 1 shows number and developmental stages of the eggs analysed every month.

The method described by Lowry et al. (1951) and modified by Maxwell et al. (1978) was used to analyse the protein content of the eggs. Egg carbohydrate content was measured by the phenol-sulphuric acid method (Dubois et al. 1956). Egg lipid content was determined using the sulphophosphovanillin method (Zöllner \& Kirsch 1962).

Total protein, carbohydrate and lipid contents of the seston fraction (20 to $1000 \mu \mathrm{m})$ were also analysed using the above methods. We assumed that the organic content of seston (total protein, carbohydrate and lipid content) in appropriate size classes could serve as an index of food availability for sardine larvae. As the body size of larvae that appear in this area ranged between 2.4 and $28 \mathrm{~mm}$, the seston size fraction measured is within the range of prey captured by such larvae (Conway et al. 1991). However, it has not been demonstrated that this seston fraction is, in fact, a good indicator of larval food availability for sardine.

Data analysis. Statistical analyses were performed with SPSS 11.0.

Table 1. Number of eggs and developmental stages collected during each sampling at all sampling stations for the biochemical analyses

\begin{tabular}{|c|c|c|c|c|c|c|c|c|c|c|c|c|}
\hline \multirow[t]{2}{*}{ Date } & \multirow{2}{*}{$\begin{array}{l}\text { No. of } \\
\text { eggs }\end{array}$} & \multicolumn{10}{|c|}{ Egg developmental stage: no. of samples } & \multirow{2}{*}{$\begin{array}{c}\text { Not } \\
\text { determined }\end{array}$} \\
\hline & & II & III & IV & $\mathrm{V}$ & VI & VII & VIII & IX & $\mathrm{X}$ & $\mathrm{XI}$ & \\
\hline Feb 1998 & 27 & 1 & 0 & 2 & 0 & 2 & 11 & 5 & 1 & 1 & 0 & 4 \\
\hline Mar 1998 & 29 & 1 & 12 & 1 & 2 & 7 & 5 & 0 & 0 & 0 & 0 & 1 \\
\hline Apr 1998 & 41 & 4 & 1 & 0 & 1 & 17 & 9 & 1 & 2 & 0 & 0 & 4 \\
\hline May 1998 & 16 & 3 & 1 & 0 & 1 & 1 & 8 & 2 & 0 & 0 & 0 & 0 \\
\hline Jun 1998 & 30 & 1 & 2 & 6 & 13 & 4 & 1 & 1 & 0 & 0 & 0 & 2 \\
\hline Feb 1999 & 21 & 1 & 0 & 2 & 4 & 1 & 2 & 0 & 0 & 0 & 0 & 11 \\
\hline Mar 1999 & 43 & 8 & 0 & 0 & 12 & 6 & 0 & 0 & 9 & 4 & 2 & 2 \\
\hline Apr 1999 & 17 & 5 & 0 & 0 & 1 & 7 & 0 & 0 & 1 & 0 & 0 & 3 \\
\hline May 1999 & 29 & 7 & 1 & 0 & 1 & 5 & 5 & 2 & 1 & 4 & 3 & 0 \\
\hline Jun 1999 & 7 & 2 & 0 & 1 & 0 & 0 & 2 & 0 & 0 & 1 & 0 & 1 \\
\hline Jan 2000 & 19 & 4 & 0 & 0 & 2 & 5 & 0 & 0 & 3 & 3 & 0 & 2 \\
\hline Feb 2000 & 10 & 3 & 4 & 0 & 0 & 2 & 1 & 0 & 0 & 0 & 0 & 0 \\
\hline Mar 2000 & 28 & 5 & 0 & 0 & 0 & 12 & 5 & 0 & 0 & 5 & 1 & 0 \\
\hline Apr 2000 & 4 & 1 & 0 & 0 & 0 & 1 & 0 & 0 & 0 & 2 & 0 & 0 \\
\hline May 2000 & 30 & 0 & 11 & 1 & 0 & 7 & 6 & 0 & 0 & 3 & 1 & 1 \\
\hline Jun 2000 & 2 & 2 & 0 & 0 & 0 & 0 & 0 & 0 & 0 & 0 & 0 & 0 \\
\hline Feb 2001 & 38 & 17 & 2 & 0 & 0 & 5 & 0 & 0 & 4 & 10 & 0 & 0 \\
\hline Apr 2001 & 18 & 0 & 0 & 0 & 0 & 16 & 0 & 0 & 0 & 2 & 0 & 0 \\
\hline May 2001 & 26 & 0 & 3 & 10 & 0 & 2 & 11 & 0 & 0 & 0 & 0 & 0 \\
\hline Jun 2001 & 28 & 0 & 6 & 3 & 8 & 2 & 3 & 2 & 2 & 2 & 0 & 0 \\
\hline
\end{tabular}




\section{RESULTS}

\section{Spawning period}

Fig. 2 shows the monthly mean abundance of sardine eggs during the $4 \mathrm{yr}$ sampling period. Sardine spawning mainly took place between January and June of each year.

Fig. 3 shows the average monthly value of Ekman transport for the $Q_{\mathrm{x}}$ component between 1875 and 1997 at the station located at $42^{\circ} \mathrm{N}, 10^{\circ} \mathrm{W}$. February and March have been highlighted because they are the months in which the largest abundance of sardine eggs was found at the sampling stations.

During the months of February and March, although there were years with $Q_{\mathrm{x}}$ lower than $-170 \mathrm{~m}^{3} \mathrm{~km}^{-1} \mathrm{~s}^{-1}$ (the threshold below which such an intense upwelling occurs that the eggs and larvae are transported towards zones far from the coast and recruitment is negatively affected; Guisande et al. 2001, 2004), the mean value was above this threshold. A $Q_{\mathrm{x}}$ above this threshold indicates that there is not a very important transport of the water mass offshore. In autumn and winter, although the transport offshore is low, food is scarce and temperatures are lower, so spawning would not be successful.

These $Q_{\mathrm{x}}$ results, added to the values for abundance of eggs and larvae at the stations, indicate that during the months when the peak of the sardine spawning is reached the transport conditions of the masses of water perpendicular to the coast result in no displacement of the eggs offshore.

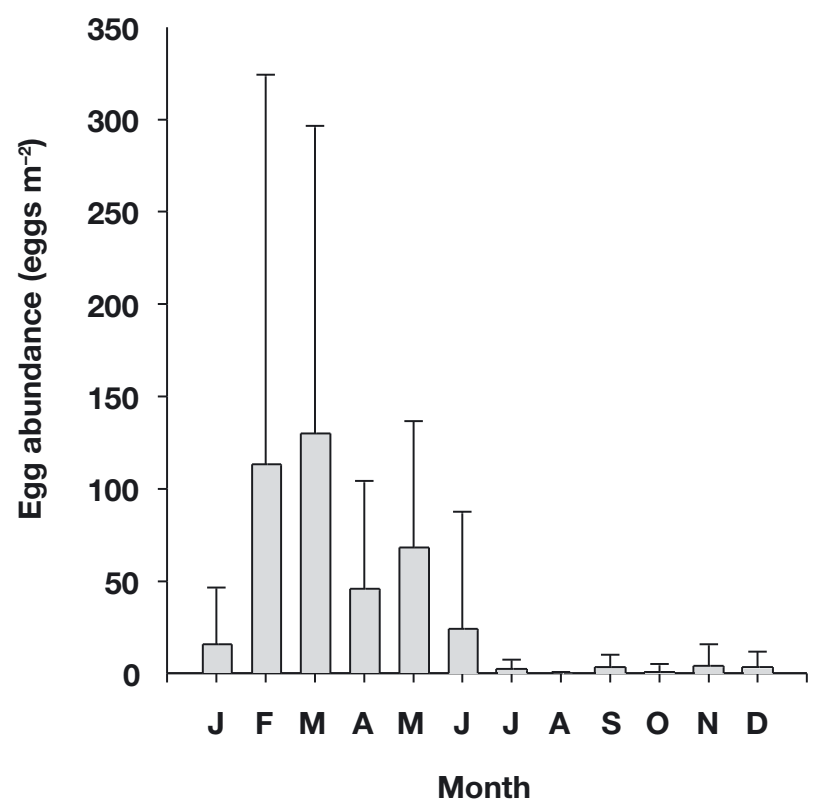

Fig. 2. Sardina pilchardus. Monthly sardine egg abundance (mean \pm SD) from 1998 to 2001 in the Ría de Vigo (northwest Spain)

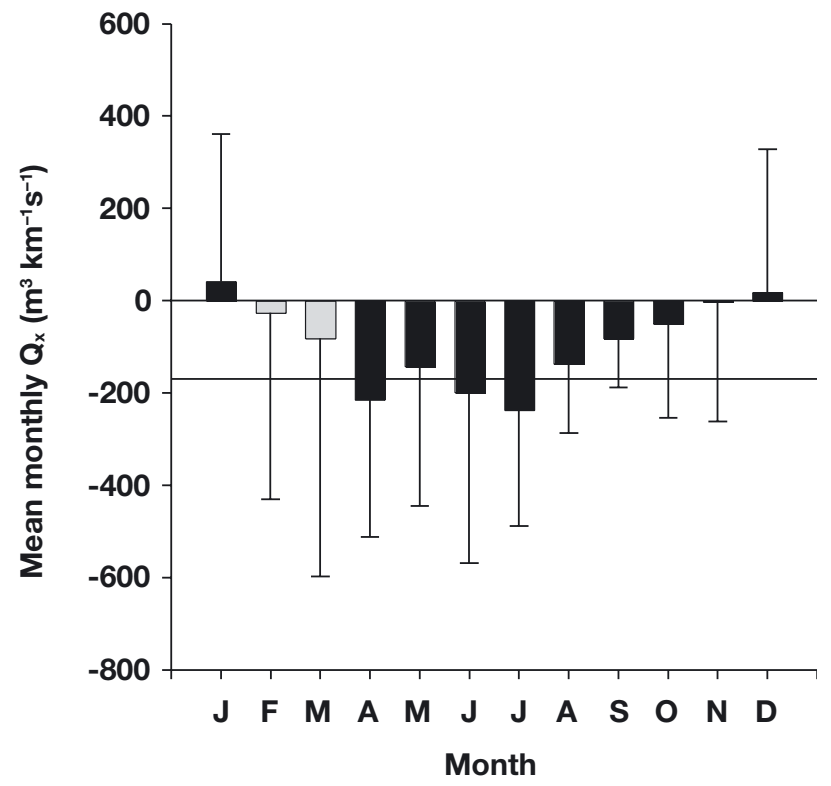

Fig. 3. Monthly Ekman transport (mean $\pm \mathrm{SD}$ ) from 1875 to 1997 at a station located at $42^{\circ} \mathrm{N}, 10^{\circ} \mathrm{W}$. Grey shaded bars indicate the months when the abundance of Sardina pilchardus eggs is highest. Solid line represents the threshold that limited the optimal environmental window for sardine recruitment success in this area (Guisande et al. 2001)

\section{Quality of the spawn}

Fig. 4 shows the evolution of egg size throughout the different months of spawning during our 4 yr sampling period. Although it seems there is a decline in egg size over the sampling period, no significant differences

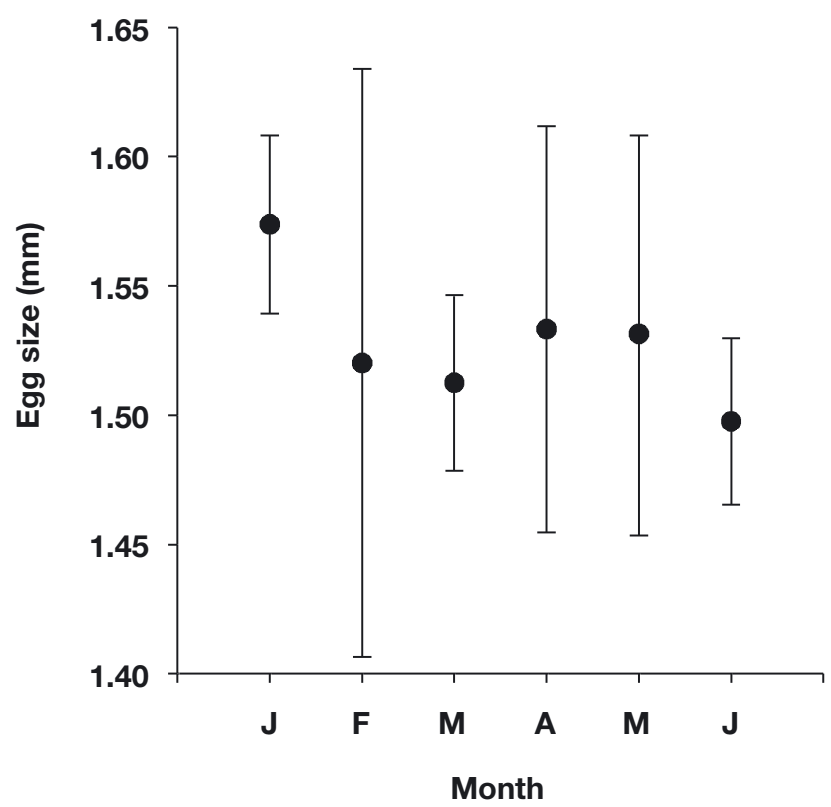

Fig. 4. Sardina pilchardus. Monthly egg size of the sardine (mean \pm SE) during the spawning period from 1998 to 2001 
in egg size were found between January and June (ANOVA, $F_{5,439}=1.7, \mathrm{p}=0.136$ ).

Regarding the biochemical composition in terms of proteins, carbohydrates, lipids and total organic content, significant differences between months were found (ANOVA, for all biochemical components $\mathrm{p}<0.001$ ) (Fig. 5).

In January (Fig. 5), the quantity of lipids present in the larvae was very low. This observation is based on a single value, i.e. that of January 2000, because we only found eggs in this month of this year (Table 1); as such, the value could be anomalous. A clear tendency towards a reduction of all the egg components was found as the spawning season progressed (Fig. $5)$. The rates of decline were different for protein $\left(5.1 \% \mathrm{mo}^{-1}\right)$, carbohydrates $\left(1.5 \% \mathrm{mo}^{-1}\right)$ and for lipids $\left(11.4 \% \mathrm{mo}^{-1}\right.$, excluding the data for January 2000).
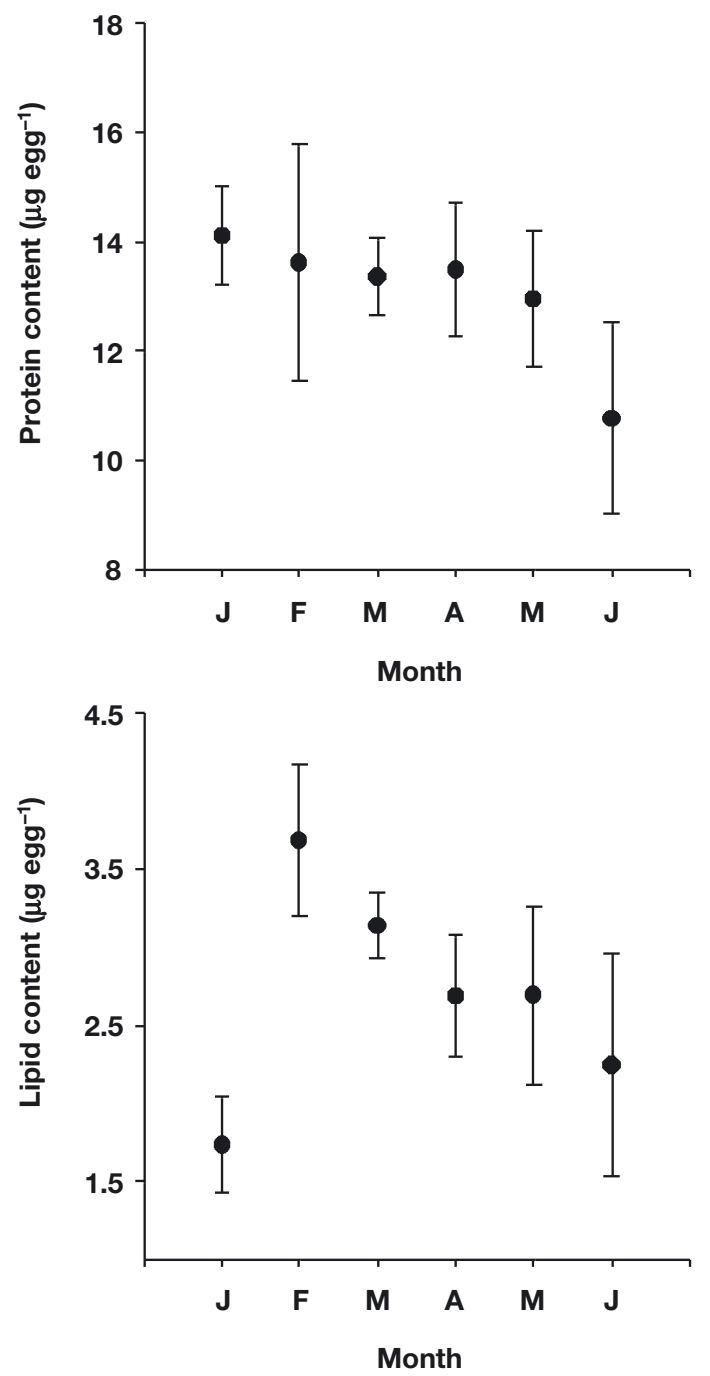

The monthly evolution of temperature during the spawning season is shown in Fig. 6, where it can be seen that the tendency is opposite to that for the biochemical composition of the eggs, increasing significantly during the spawning season as summer approaches (ANOVA, $F_{5,37}=4.1, \mathrm{p}=0.004$ ).

The results for embryonic development at different temperatures throughout the months of the spawning season revealed that the duration of development up to hatching depended mainly upon temperature (Fig. 7). However, as there were differences in the egg development time between months for the same temperature, the biochemical composition of the eggs (protein, carbohydrate and lipid contents) was included in a multiple stepwise regression. This revealed that, besides the environmental factor of temperature $(T)$, egg quality, expressed as the total protein content of the egg $\left(P, \mu\right.$ egg $\left.^{-1}\right)$, also significantly affected egg devel-
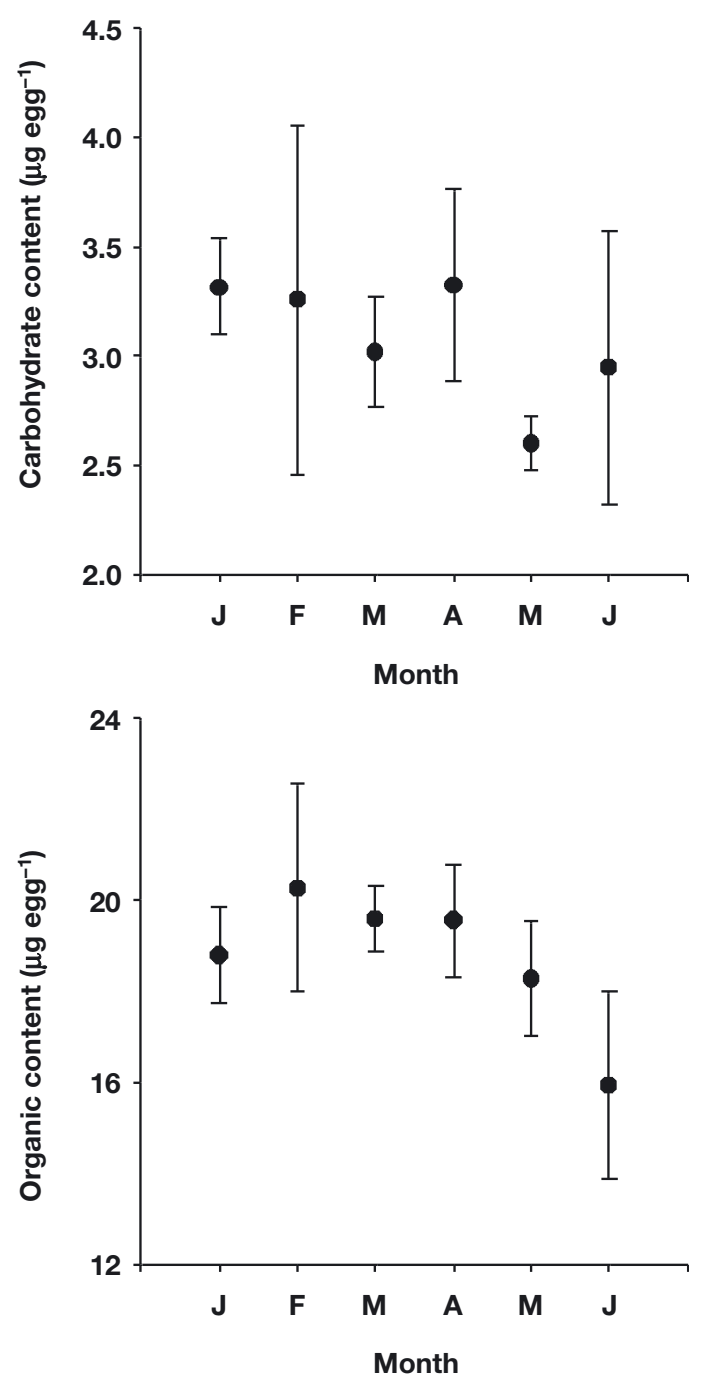

Fig. 5. Sardina pilchardus. Monthly protein, carbohydrate, lipid and organic content of the sardine egg (mean \pm SE) over the spawning period from 1998 to 2001 
opment $(D$, in hours $)\left(D=190-7.2 \cdot T-2.2 \cdot P_{;} F_{2,13}=\right.$ $\left.50.5, \mathrm{r}^{2}=0.9, \mathrm{p}<0.001\right)$. For the same incubation temperature, it was demostrated that when egg protein is higher, embryonic development time is reduced (Fig. 7).

During the spawning period there was a negative correlation between temperature and egg protein $(P=$ $40.54-1.98 \cdot T_{i} F_{1,5}=21.9, \mathrm{r}^{2}=0.85, \mathrm{p}=0.009$, Fig. 8a). Hence, this response of the duration of embryonic development, depending upon both temperature and egg quality, indicates the possible existence of a compensatory mechanism for maintaining a more or less consistent duration of development throughout the spawning season. When temperature is lower (excluding the January data for lipids, which is abnormally low), carbohydrates, lipids and egg organic content, like protein content, also have a higher value. Therefore, in the months of lower temperatures the strategy of the females may be to produce eggs with a higher organic content $(O E)$ and of higher quality. However, because of the low value of data from January 2000, this correlation is not as significant as that for proteins $\left(O E=50.7-2.3 \cdot T_{i} F_{1,5}=8.3, \mathrm{r}^{2}=0.68, \mathrm{p}=0.045\right.$, Fig. 8b).

Throughout the different sampling months, there are significant differences in the quantity of organic content of the eggs, which was significantly lower as the spawning season progressed (Fig. 5). This could be a disadvantage for larvae produced in the later months, if not compensated for by a larger quantity of food in the environment (Fig. 9). An ANOVA $\left(F_{5,40}=2.5\right.$, $\mathrm{p}=0.047$ ) showed that the seston organic content increased significantly over the spawning period.

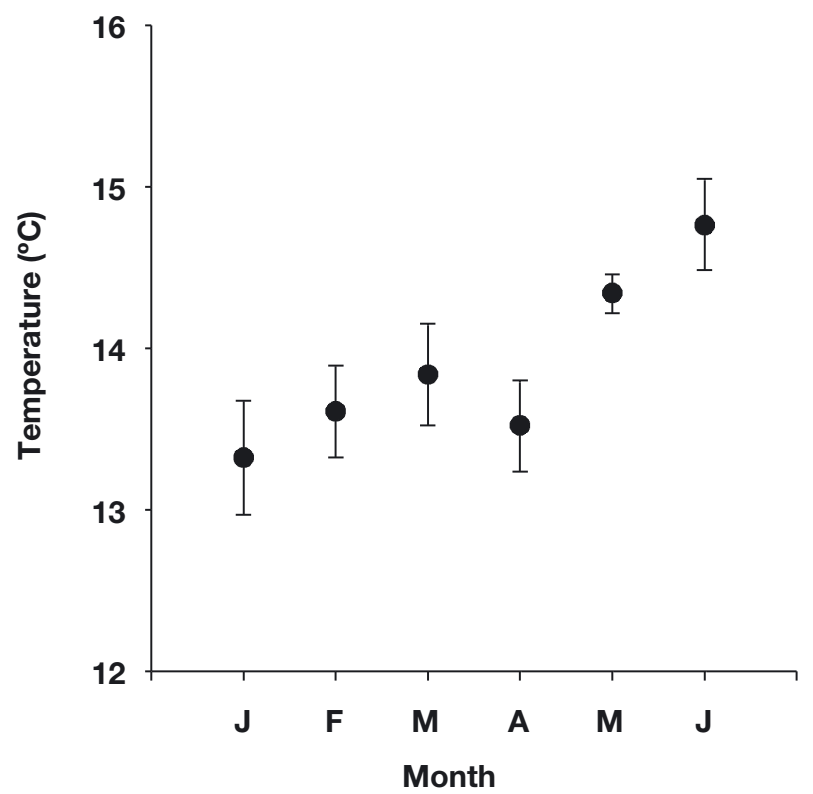

Fig. 6. Monthly temperature (mean $\pm \mathrm{SD}$ ) of the stations sampled in the Ría de Vigo from 1998 to 2001

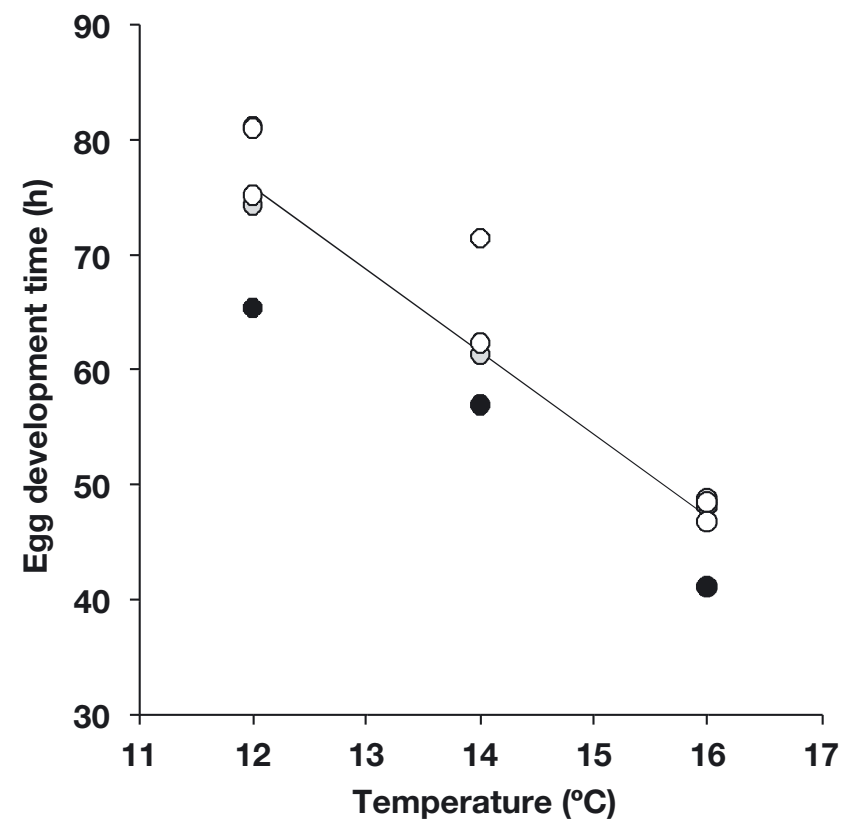

Fig. 7. Sardina pilchardus. Relationship between mean egg development time and temperature of incubation. Values for eggs with protein content higher than $14 \mu \mathrm{g}(\bullet)$, between 14 and $13 \mu \mathrm{g}(\mathrm{O})$ and lower than $13 \mu \mathrm{g}(\mathrm{O})$ are shown. All SE were lower than 4.3

\section{DISCUSSION}

The main sardine spawning period in the coastal waters of Galicia between 1998 and 2001 took place outside the normal period of upwelling, in order to reduce the offshore larval transport. This is consistent with the results of Dickson et al. (1988) and LópezJamar et al. (1995), showing a negative correlation between upwelling conditions and sardine recruitment in Galicia. The dates of birth of the surviving recruits can be exactly measured by reading the otoliths of juvenile fish. There are studies suggesting that the suitable moments for spawning coincide with the beginning of a period of calm, without winds (e.g. Álvarez \& Butler 1992). A strong phenomenon of upwelling during the months of February and March, when the sardine spawn, could cause a reduction in survival rates because of the transport of eggs towards areas where food is much less abundant (Robles et al. 1992). Larval transport is the most important factor controlling sardine recruitment success in this area, being the responsible factor for the decline in catches observed in the 1920s, 1950s and 1970s (Guisande et al. 2004).

In agreement with previous studies carried out with other species (Hart \& Purser 1995, Gadomski \& Caddell 1996, Kuyawa et al. 1997) and also for the sardine Sardina pilchardus (Miranda et al. 1990), our results show that embryonic development time gets shorter with 

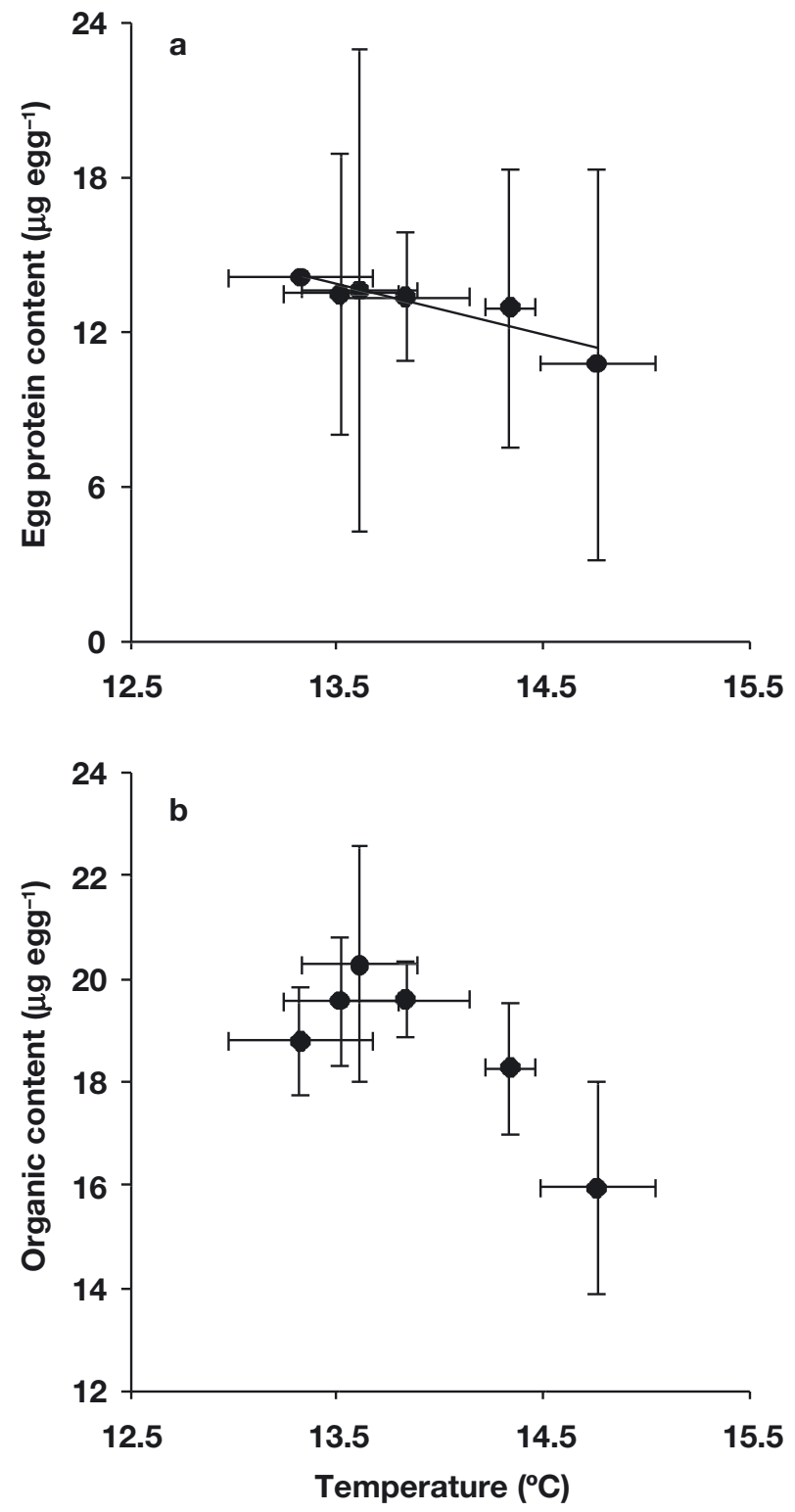

Fig. 8. Sardina pilchardus. (a) Relationship between egg protein content (mean $\pm \mathrm{SE}$ ) and monthly temperature (mean \pm SD) from 1998 to 2001. (b) Relationship between monthly egg organic content (mean \pm SE) and monthly temperature (mean \pm SD) from 1998 to 2001

increasing temperature. Bearing in mind the normal evolution of temperature in the zone (Fig. 6), which increases during the spawning period, eggs hatched in the early months of the year would have a considerable disadvantage to those hatched at the end of the spawning season. Therefore the duration of their embryonic development would be much longer than those of the later months and would be exposed to predation for more time, which is one of the main causes of mortality in fish eggs (Houde et al. 1994). Egg quality, as well as

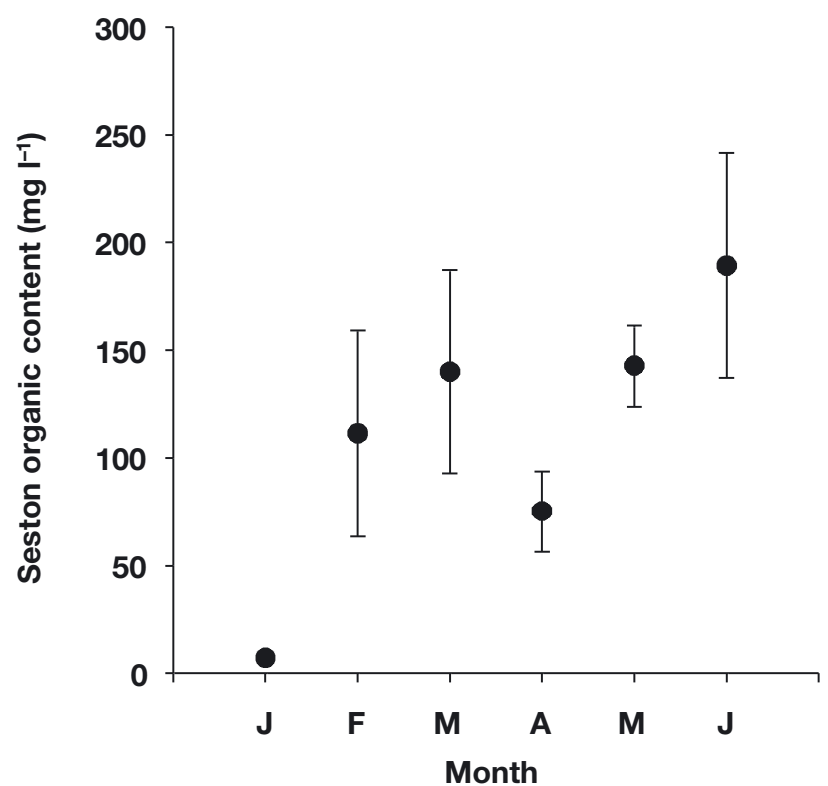

Fig. 9. Monthly organic content (mean \pm SE) of the seston fraction 20 to $1000 \mu \mathrm{m}$ in the stations of the Ría de Vigo from 1998 to 2001

temperature, is important, since during development they have to synthesise new tissue rapidly, but do not receive external energy.

Therefore, it is essential that eggs be endowed with the necessary reserves for development to occur satisfactorily and in the least time possible. The protein content of the egg, which can be an indicator of egg quality for the sardine, affects the duration of the development of the egg up to hatching, causing this period to diminish as the protein content increases. A compensatory mechanism of the females appears in this way, adapting the quality of the eggs to the normal evolution of temperature in the area. There is a negative correlation between both variables and it has been observed that eggs produced at the beginning of the spawning season, when the temperature of the water is lower, have a higher organic content (Fig. 5). This helps to reduce the time of development in the winter, bringing it closer to the duration of development in the summer. For some species it has been seen that egg size affects embryonic development, and a reduction in egg size has been observed as the spawning season progresses and temperature increases, in a way that the effect of both factors is compensated (Baynes \& Howell 1996). Devauchelle (1980) observed that females kept at a constant high temperature yielded smaller eggs than those of natural stock, subjected to the natural thermal cycle, especially during winter temperatures. Moreover, Devauchelle \& Coves (1988) found that during the normal spawning period the 
females produced eggs with more proteins, and that outside the normal spawning period produced eggs with more lipids. Hence, at the beginning of the spawning season, this strategy permits greater investment in the production of eggs with more proteins and, later, a reduction in the investment in proteins without greatly affecting the period of development. A problem would only arise if in a specific year, during spawning, deviations of temperature occurred, especially if temperature fell in the period when the females produce eggs with a lower organic content.

Limitation of food is one of the most important factors determining survival during the larval stage (Cushing 1975). Canino et al. (1991) demonstrated that when the spawning is not linked to an abundance of food, the lower concentrations of available food are insufficient to maintain optimum growth rates of larvae beginning to feed. This has considerable implications for the feeding rate and, therefore, the survival rate. In agreement with this theory, Kucharczyk et al. (1997) and Kuyawa et al. (1997) concluded that larval survival might be mainly related to high food concentrations, rather than to temperatures in the breeding habitats. Our results show that food in the zone, expressed as the organic content of the seston (Fig. 9), increases as the spawning season progresses, while the evolution of the organic content of the egg is reduced as that of the seston increases (Fig. 5). The organic content of the newly hatched larvae may depend to a great extent upon the total organic content of the eggs. Hence, the larvae hatching in the early months of the year, when food is more scarce, could compensate for this with a higher quantity of body organic content, which may provide the larvae with a greater robustness when starting to swim and search for food, at a time when it is least abundant.

Acknowledgements. This research was supported by the projects REN2002-04205-C04-01， XUNTA DE GALICIA PGIDIT03PXIC30106PN and REN2002-04205-C04-01.

\section{LITERATURE CITED}

Álvarez F, Butler JL (1992) First attempt to determine birthdates and environmental relationship of juvenile sardine, Sardina pilchardus (Walb.) in the region of Vigo (NW Spain) during 1988. Bol Inst Esp Oceanogr 8:115-121

Araújo-Lima CARM (1994) Egg size and development in Central Amazonian fish. J Fish Biol 44:371-389

Bailey KM, Canino MF, Napp JM, Spring SM, Brown AL (1995) Contrasting years of prey levels, feeding conditions and mortality of larva wallege pollock Theragra chalcogramma in the western Gulf of Alaska. Mar Ecol Prog Ser 119:11-23

Bakun A (1986) Definitions of environmental variability affecting biological processes in large marine ecosystems. In: Sherman K, Alexander LM (eds) Variability and man- agement of large marine ecosystems. Westview Press, Boulder, CO, p 89-108

Banegal TB (1969) Relationships between egg size and fry survival in brown trout, Salmo trutta L. J Fish Biol 1: 349-353

Baynes SM, Howell BR (1996) The influence of egg size and incubation temperature on the condition of Solea solea (L.) larvae at hatching and first feeding. Aquaculture 199: $59-77$

Bisbal GA, Bengtson DA (1995) Description of the starving condition in summer flounder, Paralichthys dentatus, early life history stages. US Nat Mar Fish Serv Fish Bull 93: $217-230$

Blaxter JHS, Hempel G (1963) The influence of egg size on herring larvae (Clupea harengus L.). J Cons Perm Int Explor Mer 28:211-240

Brown RW, Taylor WW (1992) Effects of egg composition and prey density on the larval and survival of lake whitefish (Coregonus clupeaformis Mitchill). J Fish Biol 40:381-394

Buckley LJ, Smigielski AS, Halavik TA, Laurence GC (1991) Effects of water temperature on size and biochemical composition of winter flounder Pleuropseudonectes americanus at hatching and feeding initiation. Fish Bull 88: $419-428$

Canino MF, Bailey KM, Incze LS (1991) Temporal and geographic differences in feeding and nutritional condition of walleye pollock larvae Theragra chalcogramma in Shelikof Strait, Gulf of Alaska. Mar Ecol Prog Ser 79:27-35

Chambers RC, Waiwood KG (1996) Maternal and seasonal differences in egg sizes and spawning characteristics of captive Atlantic cod, Gadus morhua. Can J Fish Aquat Sci 53:1986-2003

Chícharo MA, Chícharo L, Valdés L, López-Jamar E, Ré P (1998) Estimation of starvation and diel variation of the RNA/DNA ratios in field-caught Sardina pilchardus larvae off the north of Spain. Mar Ecol Prog Ser 164:273-283

Cole J, McGlade J (1998) Clupeoid population variability, the environment and satellite imagery in coastal upwelling systems. Rev Fish Biol Fish 8:445-471

Conway DVP, Tranter PRG, Fernández de Puelles ML, Coombs SH (1991) Feeding of larval sprat (Sprattus sprattus L.) and sardine (Sardina pilchardus Walbaum). ICES CM Biol Oceanogr Committee 76:1-7

Craik JCA, Harvey SM (1987) The causes of buoyancy in eggs of marine teleosts. J Mar Biol Assoc UK 67:169-182

Cury P, Bakun A, Crawford MRJ, Jarre A, Quiñones RA, Shannon LJ, Verheye HM (2000) Small pelagics in upwelling systems: patterns of interation and strutural changes in 'wasp-waist' ecosystems. ICES J Mar Sci 57: $603-618$

Cushing DH (1975) Marine ecology and fisheries. Cambridge University Press, Cambridge

Devauchelle N (1980) Étude experiméntale sur la réproduction, les oeufs et les larves de bar (Dicentrarchus labrax), daurade (Sparus aurata), mulet (Liza ramada), rouget (Mullus surmuletus), sole (Solea solea) et turbot (Scophthalmus maximus). PhD thesis, University of Brest, Brest

Devauchelle N, Coves D (1988) The characteristics of sea bass (Dicentrarchus labrax) eggs: description, biochemical composition and hatching performances. Aquat Living Resour $1: 223-230$

Dickson RR, Kelly PM, Colebrook JM, Wooster WS, Cushing DH (1988) North winds and production in the eastern North Atlantic. J Plankton Res 10:151-169

Dubois M, Gilles KA, Hamilton JK, Smith F (1956) Colorimetric method for determination of sugars and related substances. Anal Chem 28:350-356 
Farris DA (1960) Failure of an anchovy to hatch with continued growth of the larva. Limnol Oceanogr 5:107

Finn RN, Henderson JR, Fyhn HJ (1995) Physiological energetics of developing embryos and yolk-sac larvae of Atlantic cod (Gadus morhua). II. Lipid metabolism and enthalpy balance. Mar Biol 124:371-379

Frèon P, El-Khatabi M, Mendoza J, Guzmán R (1997) Unexpected reproductive strategy of Sardinella aurita off the coast of Venezuela. Mar Biol 128:363-372

Fyhn HJ, Govoni JJ (1995) Endogenous nutrient movilization during egg and larval development in 2 marine fishesAtlantic menhaden and spot. ICES J Mar Sci Symp 201: 64-69

Gadomski DM, Caddell SM (1996) Effects of temperature on the development and survival of eggs of 4 coastal California fishes. Fish Bull 94:41-48

Gamulin Y, Hure J (1955) Contribution a la naissance de la ponte de la sardine (Sardina pilchardus Walbaum), dans l'Ádriatique. Acta Adriática 7:1-23

Guisande C, Cabanas JM, Vergara AR, Riveiro I (2001) Effect of climate on recruitment success of Atlantic Iberian sardine Sardina pilchardus. Mar Ecol Prog Ser 223:243-250

Guisande C, Vergara AR, Riveiro I, Cabanas JM (2004) Climate change and abundance of the Atlantic Iberian sardine (Sardina pilchardus). Fish Oceanogr 13:91-101

Gunasekera RM, De Silva SS, Ingram BA (1999) Early ontogeny-related changes of the fatty acid composition in the Percichtyid fishes trout cod, Maccullochella macquariensis and Murray cod, M. peelii peelii. Aquat Living Resour 12: 219-227

Hart PR, Purser GJ (1995) Effects of salinity and temperature on eggs and yolk sac larvae of the greenback flounder (Rhombosolea tapirina Günther, 1862). Aquaculture 136: 221-230

Hinkley S (1990) Variation of egg size of walleye pollock Theragra chalcogramma with a preliminary examination of the effect of egg size on larval size. Fish Bull US 88:471-483

Houde EE, Gamble JC, Dorsey SE, Cowan JH (1994) Drifting mesocosms: the influence of gelatinous zooplankton on mortality of bay anchovy, Anchoa mitchilli, eggs and yolksac larvae. ICES J Mar Sci 51:383-394

Hunter JR (1981) Feeding ecology and predation of marine fish larvae. In: Lasker R (ed) Marine fish larvae. University of Washington Press, Seattle, WA, p 33-77

Hutchings JA (1994) Age- and size-specific costs of reproduction within populations of brook trout, Salvelinus fontinalis. Oikos 70:12-20

Imai C, Tanaka S (1998) Effect of egg size on the suvival potential in first-feeding larvae of Japanese anchovy. Nippon Suisan Gakkaishi 64:8-15

Kamler E, Szlaminska M, Kuczynski M, Hamackova J, Kouril J, Dabrowski R (1994) Temperature-induced changes of early development and yolk utilization in the African catfish Clarias gariepinus. J Fish Biol 44:311-326

Kristjánsson LT, Vøllestad LA (1996) Individual variation in progeny size and quality in rainbow trout, Oncorhynchus mykiss (Walbaum). Aquat Res 27:335-343

Kucharczyk D, Luczynski M, Kujawa R, Czerkies P (1997) Effect of temperature on embryonic and larval development of bream (Abramis brama L.). Aquat Sci 59:214-224

Kuyawa R, Mamcarz A, Kucharczyk D (1997) Effect of temperature on embryonic development of asp (Aspius aspius L). Polskie Archiwum Hydrobiologii 44:139-143

Lagomarsino IV, Francis RC, Barlow GW (1988) The lack of correlation between egg size and size of the hatchling in the Midas cichild, Cichlasoma citrinellum. Copeia 1988: 1086-1089
López-Jamar E, Coombs SH, García A, Halliday NC, Knust R, Nellen W (1995) The distribution of sardine Sardina pilchardus (Walbaum, 1792) off the north and north-western Atlantic coast of the Iberian Peninsula, in relation to environmental conditions. Bol Inst Esp Oceanogr 11:27-46

Lowry OH, Rosenbraugh NJ, Farr AL, Randall RJ (1951) Protein measurements with the Folin phenol reagent. J Biol Chem 193:256-275

MacKenzie BR, St John M, Wieland K (1996) Eastern Baltic cod: perspectives from existing data on processes affecting growth and survival of eggs and larvae. Mar Ecol Prog Ser 134:265-281

Marteinsdottir G, Steinarsson A (1998) Maternal influence on the size and viability of Iceland cod Gadus morhua eggs and larvae. J Fish Ecol 52:1241-1258

Maxwell MAK, Haas SM, Bieber LL, Tolbert NE (1978) A modification of the Lowry procedure to simplify protein determination in membrane and lipoprotein samples. Anal Biochem 87:206-210

McEvoy LA, McEvoy J (1991) Size fluctuations in the eggs and newly hatched larvae of captive turbot (Scophthalmus maximus). J Mar Biol Assoc UK 71:679-690

Millán M (1999) Reproductive characteristics and condition status of anchovy Engraulis encrasicolus L. from the Bay of Cadiz. Fish Res 41:73-86

Miller TJ, Crowder LB, Rice JA, Marschall EA (1988) Larval size and recruitment mechanisms in fishes: toward a conceptual framework. Can J Fish Aquat Sci 45:1657-1670

Miranda A, Cal RM, Iglesias J (1990) Effect of temperature on the development of eggs and larvae of sardine Sardina pilchardus Walbaum in captivity. J Exp Mar Biol Ecol 140: 69-77

Nissling A, Larsson R, Vallin L, Frohlund K (1998) Assessment of egg and larval viability in cod, Gadus morhua: methods and results from an experimentary study. J Fish Res 38 169-186

Pepin P, Orr DC, Anderson JT (1997) Time to hatch and larval size in relation to temperature and egg size in Atlantic cod (Gadus morhua). Can J Fish Aquat Sci 54:2-10

Pickova J, Dutta PC, Larsson PO, Kiessling A (1997) Early embryonic cleavage pattern, hatching success, and egg-lipid fatty acid composition: comparison between 2 cod (Gadus morhua) stocks. Can J Fish Aquat Sci 54: $2410-2416$

Planas M, Estévez A, Garrido JL (1991) Energy metabolism during early ontogenesis of turbot (Scophthalmus maximus) and the effect of starvation. Eur Aquacult Soc Spec Publ 15:210-212

Riveiro I, Guisande C, Lloves M, Maneiro I, Cabanas JM (2000) Importance of parental effects on larval survival in Sardina pilchardus. Mar Ecol Prog Ser 205:249-258

Robles R, Porteiro C, Cabanas JM (1992) The stock of AtlantoIberian sardine: possible causes of variability. ICES Mar Sci Symp 195:418-423

Rønnestad I, Koven W, Tandler A, Harel M, Fyhn HJ (1998) Utilization of yolk fuels in developing eggs and larvae of European sea bass (Dicentrarchus labrax). Aquaculture 162:157-170

Rønnestad I, Thorsen A, Finn RN (1999) Fish larval nutrition: a review of the recent advances in the roles of amino acids. Aquaculture 177:201-216

Rooker JR, Holt GJ (1996) Application of RNA:DNA ratios to evaluate the condition and growth of larval and juvenile red drum (Sciaenops ocellatus). Mar Freshw Res 47: $283-290$

Sargent RC, Taylor PD, Gross MR (1987) Parental care and the evolution of egg size in fishes. Am Nat 129:32-46 
Sivaloganathan B, Waldford J, Ip YK, Lam TJ (1998) Free amino acids and energy metabolism in eggs and larvae of seabass, Lates calcarifer. Mar Biol 131:695-702

Skolbekken R, Utne-Palm AC (2001) Parental investment of male-two spoted goby Gobiusculus flavescens (Fabricius). J Exp Mar Biol Ecol 261:137-157

Srivastava RK, Brown JA (1991) The biochemical characteristics and hatching performance of cultured and wild Atlantic salmon (Salmo salar) eggs. Can J Zool 69: $2436-2441$

Suthers IM, Cleary JJ, Battaglene SC, Evans R (1996) Relative RNA content as a measure of condition in larval and juvenile fish. Mar Freshw Res 47:301-307

Takii K, Miyashita S, Seoka M, Tanaka Y, Kubo Y, Kumai H

Editorial responsibility: Otto Kinne (Editor),

Oldendorf/Luhe, Germany
(1997) Changes in biochemical contents and enzyme activities during embryonic development of bluefin tuna. Fish Sci 63:1014-1018

Tamaru CS, Ako H, Lee CS (1992) Fatty acid and amino acid profiles of spawned eggs of striped mullet, Mugil cephalus L. Aquaculture 105:83-94

Woodruff SD, Slutz RJ, Jenne RL, Steurer PM (1987) A comprehensive ocean-atmosphere data set. Bull Am Meteorol Soc 68:1239-1250

Zöllner N, Kirsch K (1962) Über die quantitative Bestimmung von Lipoiden (Mikromethode) mittels der vielen natürlichen Lipoiden (allen bekannten Plasmalipoiden) gemeinsamen Sulfophosphovanillin. Z Gesamte Exp Med $135: 545-561$

Submitted: October 14, 2003; Accepted: April 6, 2004

Proofs received from author(s): June 3, 2004 